Article

\title{
Digital Technology Platforms as an Innovative Tool for the Implementation of Renewable Energy Sources
}

\author{
Krzysztof Bartczak
}

check for

updates

Citation: Bartczak, K. Digital Technology Platforms as an Innovative Tool for the Implementation of Renewable Energy Sources. Energies 2021, 14, 7877. https://doi.org/10.3390/en14237877

Academic Editor: Marek Szarucki

Received: 15 October 2021

Accepted: 22 November 2021

Published: 24 November 2021

Publisher's Note: MDPI stays neutral with regard to jurisdictional claims in published maps and institutional affiliations.

Copyright: (C) 2021 by the author. Licensee MDPI, Basel, Switzerland. This article is an open access article distributed under the terms and conditions of the Creative Commons Attribution (CC BY) license (https:// creativecommons.org/licenses/by/ $4.0 /)$.
Faculty of Management, Warsaw University of Technology, 02-524 Warsaw, Poland; krzysztof.bartczak@pw.edu.pl

\begin{abstract}
The subject matter addressed in the paper concerns digital technology platforms in the context of renewable energy sources. The main goal is to check whether digital technology platforms can be effective factors in implementing innovative business models in the RES sector. The study was based on empirical research using Computer-Assisted Telephone Interview (CATI) and ComputerAssisted Web Interview (CAWI) methods, as well as on a model of attitudes towards digital technology platforms (DTPs) built using CATREG (categorical regression) analysis. As a result of the research, it was found that digital technology platforms contribute to building innovative business models. The decisive influence on this is a number of benefits for enterprises and consumers (and the related factor is the most important when it comes to attitudes towards DTP), as well as the high interest in digital RES platforms.
\end{abstract}

Keywords: innovation; digital technology platforms; renewable energy; business model

\section{Introduction}

The research on digital technology platforms (DTPs) that will be discussed in this paper was carried out in a broad context. It concerns broadly understood digitisation or digitalisation, which was already discussed in the early 1970s by R. Wachal [1], which concerns the digital transformation of enterprises, consisting of a gradual increase in the use of digital and computer technologies [2]. The subject discussed herein is also related to innovation, the expression of which is the functioning and constant intensive development of many DTPs, now considered one of the most important types of digital innovation [3-6]. Various RES (renewable energy sources) platforms also feature innovation qualities. Therefore, this part of the paper addresses basic theoretical issues related to the mentioned aspects.

First, let's focus our attention on DTPs. This concept is related to the term "digital platform". The platform, according to M.A. Cusumano [7] is a type of base that consists of specific components. The platform enables constant creation and building of a diversified set of related products and services. The digital platform, according to the approach proposed by C. Sørensen, M. de Reuver and R.C. Basole [8], is an extensible code base. Its basic feature is that it is possible to add new modules and functionalities to it at any time. Each digital platform, according to these authors, consists of a variety of technical components, including hardware and software, and related organizational processes and standards. The digital platform can also be seen as a collection of digital assets that allows users to perform specific tasks and interact with other people in a variety of ways [9].

DTP are differently recognised in the academic literature either as digital platforms [8-10], or as digital business technology platforms [11], IT platforms [12] or technology platforms [13]. DTPs are defined as digital tools that allow for the establishment and intensification of relationships between various market players, including businesses and consumers, and even administrative institutions (public administration bodies). This occurs by enabling these entities to make transactions and establish interactions, including 
business ones and those used to communicate with each other using the internet. The direct effect of this is linking business partners and create business networks [9,12]. Another definition indicates that DTPs are tools that allow specific stakeholders to unite under a common vision and approach development in specific areas, which may relate to both a strict business sphere and, more generally, social or technological ones [14]. DTPs can also be considered general-purpose technologies, consisting of various applications that create the basis for activities related to these applications [15].

Due to the fact that the scientific literature provides a number of various definitions of DTPs, our own approach to these platforms was developed and presented below. It emphasises that DTPs are electronic (digital) tools that may take the form of services or content, and which make it possible to develop the ground for establishing and intensifying contacts between different entities operating in the market; whereas a vital feature of these platforms is the possibility of their constant expansion with new modules or functionalities.

Digital technology platforms can be an effective factor in creating and developing innovative business models. This applies in particular to digital models, in which the emphasis is placed on the effective management of innovations and IT technologies and the use of all related competitive advantages [16,17]. It is worth emphasizing that in such models it is important to constantly generate knowledge, with close correlation between various service packages, as well as the participation of clients in business processes. Such functionalities are offered by DTPs [18].

It is also important that DTPs themselves are also recognized by many authors as separate business models [19-21]. In this context, Rothwell [22] emphasised that we can now speak of the fifth generation of business models, characterized by the fact that they are innovative and are associated with the creation of highly developed networks of connections. Importantly, such models are inextricably linked with information and communication technologies, which in turn are based on the Internet [23]. DTP have such features, which implies the fact that they are also modern business models.

Digital technology platforms, like no other, are the basis for promoting complex networks of connections between various types of entities operating on specific markets. Such connections are created in complex ecosystems in which interoperability and the possibility of constant modernisation of already applied solutions are at the fore [24]. Importantly, each DTP can be defined as two-way sales, leading to the co-creation of a specific value by market participants [25]. Digital technology platforms therefore allow for complex collaboration between a variety of actors.

DTPs are now also widely used in the energy sector, including activities related to the design and implementation of systems and tools in the field of renewable energy sources. With regard to the above, the terms digital energy platforms [26-29], digital platforms in the energy field [30], electronic platforms of energy [31], platforms for energy trading and risk management (abbreviated as ETRM) [32] or, more broadly, digital industry (industrial) platforms $[12,33]$ and digital manufacturing platforms $[34,35]$ are of key importance for the considerations undertaken in this paper. In scientific discussions, it is pointed out that the platforms that are used in the energy sector are the result of digitisation and the increasing use of modern digital technologies. The need to reach for such technologies within the energy market is related to the constantly growing needs of the various players operating in this market, including energy companies and consumers [36].

The use of DTPs in relation to RES is part of a broader concept related to sustainable development. It is an idea whose main goal is rational management of resources and promotion of stable economic development and social welfare. As part of sustainable development, goals are to be achieved, including the elimination of poverty and hunger, improving people's access to food and water, and increasing the quality of education. This is to ensure that the needs of modern society are provided without prejudice to the needs of subsequent generations [37,38].

Environmental aspects play an important role in this concept. Sustainable development is not possible without increasing the efficiency in the management of natural 
resources, which are depleted faster and faster. In this context, projects in the field of renewable energy sources are of key importance, thanks to which it is possible not only to obtain additional, relatively cheap energy, but also to stop negative climatic changes and improve the condition of the natural environment [36]. Currently, the use of digital technological platforms in the field of renewable energy offers particularly broad prospects. They allow for the efficient management of systems used to obtain energy from renewable sources, as well as for the intensification of cooperation in this area between many entities [39].

DTPs, in the context of the energy market, are defined as extensible system code bases based on specific software, which ensure the implementation of specific functions through the use of supporting applications [40]. Such functions may refer to the management and coordination of various energy systems, including those that control heating and airconditioning equipment [41], and the coordination of these systems and resources within them [42,43], as well as the decentralisation of the energy sector [30] or energy trading [44].

Among other functionalities related to the use of DTP in the field of renewable energy sources, there are also those related to the automatic management of processes related to energy generation using intelligent distribution networks and with strong customer involvement $[45,46]$. It is also important to use digital platforms to obtain renewable energy from dispersed resources and to effectively manage energy flows between suppliers and customers. This includes acquiring data from smart meters and on this basis providing data on energy demand prediction. DTP is also a useful tool for mutual communication and information exchange between users, including, for example, with regard to accessing products, services and resources provided by other entities or sharing advice on the practical use of RES $[47,48]$.

One more aspect should be mentioned here. The point is that digital platforms allow for the creation and development of crowdfunding solutions (financing various types of projects by the community) or crowdsourcing (participation by Internet users in tasks carried out by a specific organization). Such solutions also apply to renewable energy. DTP allows for the financing of tasks in this field, which is beneficial both for users focused on the idea of sustainable development, as well as for enterprises and organizations (imagerelated issues) $[49,50]$.

Green energy platforms, thanks to their many functions, can thus significantly contribute to the digitization, decarbonization, and decentralization of the energy sector [51].

Due to the many different functionalities, the possibility of adding new modules, as well as promoting the network of various connections, it seems reasonable to say that it is largely thanks to DTP that it is possible to intensify the development of RES. In this respect, a business model referred to as the manufacturing model, i.e., of the direct manufacturer, may be particularly useful. It is used by individual organizations to establish direct relationships with customers. Another model worth mentioning here is the brokerage model. As part of it, organizations, thanks to DTP, create virtual markets where it is possible to establish contacts and carry out purchase and sale transactions by bidders and consumers $[52,53]$.

It is worth noting that various installations are currently built on an increasingly large scale which, thanks to DTPs, operate partially or fully digitally. These include:

- digital gas and steam power plants [54-56]

- digital wind farms [57-60]

- digital hydropower plants [61-65]

- digital grids - these are systems that allow the effective, efficient, and cost-effective coordination of energy transmission between production and consumption sites, ensuring a match between demand and supply [66]

- distributed energy resources [67-69]

- $\quad$ systems related to the digitalisation of energy consumption [70-72]

There are numerous examples of successful implementations of renewable energy projects in which DTPs have played an important role. In Poland and other EU countries, broad prospects in this regard are provided by EU funds, which are directed, inter alia, 
to the increase in the importance of renewable energy sources in the energy sector. In Poland, the greatest absorption of funds from these funds concerns rural and urban-rural communes, including areas located in the eastern parts of the country. The most frequently implemented projects were those related to the improvement of the energy efficiency of existing facilities (thermal modernization, reconstruction of ventilation and air-conditioning installations, replacement of heating boilers) and the construction of renewable energy installations. In the case of renewable energy, it has been used in particular projects in the field of solar energy-photovoltaics, as well as the construction of wind farmsthe largest facilities of this type are located in Potegowo, Margonin and Banie [73,74].

The interest in such investments is very high, both on the part of public authorities, which, as part of their tasks, are obliged to neutralise the negative effects of environmental degradation by humans, and private investors, including individual farms. This creates wide perspectives. It is worth emphasising that the implementation of innovative energy projects was and is possible to a large extent thanks to digital technology platforms. DTP is responsible for the effective management of these projects, the implementation of modern technologies and the intensification of cooperation between various entities, including public-private partnerships [75,76].

DTPs which are used in the energy sector are built from several essential components. These include various types of digital applications, transmission protocols and systems that allow for data collection, storage, and analytics [77]. It is necessary to emphasise that DTPs are being increasingly used to implement innovations, including in the field of renewable energy sources. This is proven by the analyses and studies that have been discussed in the scientific literature, also related to the hydropower or electricity sectors [78].

The main objective of the present paper is to describe and evaluate the impact of DTPs on the implementation of RES projects. The main discussion will be focused on determining whether DTPs can have an impact on the implementation of innovative business models in the RES sector. The paper will be of great importance due to the fact that, for the first time, analysis of the correlation between DTP implementation and RES development will be based on the research in which, apart from using the CATI or CAWI method, a model of attitudes towards digital technology platforms was constructed. The article is a significant contribution to the development of knowledge on the use of modern technologies in the field of renewable energy, presenting attitudes towards RES platforms and the role of DTPS in the development of innovative business models in the energy sector.

\section{Materials and Methods}

For the purposes of this paper, research was carried out using a variety of methods. It should be noted that the study was based on two research projects. The first of these, entitled "Business Models Based on Digital Technology Platforms", was carried out using CATI and CATREG (categorical regression) methods. The second project, entitled "Design and Customisation Platforms for Renewable Energy Installations", used CATI and CAWI methods.

As far as CATI is concerned, in the first project, research using the method of standardised questionnaire interviews was carried out between the 18 and 28 of February, 2019. They were based on a survey questionnaire consisting of 23 questions. The CATI method features a high degree of standardisation, and it is an element of the quantitative paradigm whereby its main advantage is that its results can be generalised to the entire population [79].

The sample was randomly selected. Interviews were conducted with representatives of the management staff who know how the DTPs operate and how companies use them. The sampling frame included the list of beneficiaries of the Innovative Economy Operational Programme implemented by the (PARP) Polish Agency for Enterprise Development. The sample consisted of enterprises that were granted funding under this programme for the implementation and development of DTPs. The final sample consisted of $n=320$ records, out of which effective interviews were conducted with $n=121$ entities. 
The randomisation algorithm incorporated into the software for telephone interviews ensured that each record in the database had an equal chance of being included in the sample. In the course of the survey, each business was contacted by phone. In total, 121 interviews were completed, 49 companies refused to participate in the research, 2 companies declared that they had not implemented any platforms, and the remaining companies could not be interviewed within the timeframe set for the research.

Using CATREG (categorical regression) analysis, a model of measurement of attitudes towards DTPs was developed. Building a model of a phenomenon consists of a specific mathematisation of hypotheses (in the form of an equation or a system of equations, respectively), i.e., presenting them in a parameterised manner in the so-called 'statistical space'. Such a model presents simplified but essential and the most important relations between the analysed phenomena. Tools of inductive statistics, most often including regression models, are used for this purpose.

The concept of attitude is deeply rooted in the social sciences, particularly in sociology, but it is also widely used in economics [80]. Academics agree that attitude has a threeelement structure: affective (what one feels), cognitive (what one knows), and behavioural (what one does) [81-83]. The concept of attitude was used to develop Question 13 of the survey questionnaire, which is an indicator of the independent variable: "To what extent do DTPs influence the increase in quality and intensity of the relationships established by the company in which you perform your professional duties with all stakeholdersincluding mainly suppliers, contractors, distributors or customers?"

This question made it possible to measure attitudes towards the DTPs. It includes both evaluative elements referring to knowledge and concerning the evaluation of this phenomenon ("increase in quality and intensity"). Interrelationships between the general assessment of the impact of DTPs on the increase in quality and intensity of a company's operations and other evaluative elements-including cognitive (attitudes of members of the management towards the implementation of the DTP and the impact of DTPs on the establishment and development of innovative business models) and behavioural (areas of DTP implementation in companies-as well as benefits and threats resulting from this implementation) can be observed. The influence of socio-demographic variables related to the enterprise (type of enterprise and industry) was also analysed, and the probable influence of latent variables concerning the respondent (gender, age, level of education, work experience, time the company has been on the market). It was assumed that the company may be transformed by DTPs in the human dimension (evaluation of this phenomenon, the scope of using this phenomenon, expectations, etc.), in the cyber-security dimension (new IT challenges related to hardware and software), economic dimension (related to actual and potential profits and losses), and social dimension (changes in the structure of the company and its layout, type and intensity of relations with the company environment).

The model was constructed using the variables presented, indicating which variables and how strongly they interact with the independent variable. CATREG (categorical regression) was used for the analysis. The analytical technique made it possible to reveal the correlates of assessment of the degree to which DTPs influence the functioning of the company. The purpose of using this method was to quantify the relationships between multiple independent variables and one dependent variable. It was a "qualitative regression", and its essence is that the combined effect of the variables is examined (interaction means the "product" of individual variables). Some of the basic factors that influenced the choice of CATREG is that the method improves the traditional regression model and is more statistically correct and rigorous than correspondence analysis and multidimensional scalling (MDS). Compared to OLS regression, CATREG is more flexible and useful for handling extensive data sets containing categorical variables. Another great advantage of CATREG is that the model measures the relative importance of the explanatory variables, which facilitates the comparison of the consequences of various factors and the identification of the most important determinants [84-88]. 
At this point, it is worth presenting the variables, which were used to construct the model of attitudes towards DTPs. These variables are shown in Table 1.

Table 1. Variables used to construct the model of attitudes towards DTPs.

\begin{tabular}{lc}
\hline \multicolumn{1}{c}{ Questionnaire Survey Questions } & Factor \\
\hline Q. 11. Please specify: what key benefits are generated due to using DTPs in & economic \\
your business? & structural (socio-demographic) \\
Q. 23. Industry in which your company operates? & structural \\
Q. 14. The implementation of DTP in the company where you perform your & \\
professional duties is forced, or will it force specific changes in its & \\
organizational structure? & evaluations) \\
Q. 19. Work experience in the company where you currently perform your & structural \\
professional duties. & structural \\
Q. 4. What types of DTP are or will be used in your company? & structural \\
Q. 12. Do you agree with the statement that DTP enables the creation and & human \\
development of innovative business models? & human \\
Q. 10. In what areas of your company's activity is or will be used DTP & Q. 21. What type of position do you hold in the company in which you \\
currently perform your professional duties? & \\
Q. 18. Specify your level of education & \\
\hline
\end{tabular}

The model includes five variables belonging to the structural factor, three (although with lower explanatory power) variables belonging to the human factor, and one variable which is an economic factor (the strongest, however, of all the variables).

The second research project was carried out between 9 and 13 of November, 2020. To maximise the cognitive result, two samples of respondents were tested: individual respondents, who were surveyed using the CAWI technique, and institutional respondents (companies offering energy generation systems from renewable sources), who were interviewed using the CATI technique. The methods were chosen primarily according to their advantages. Firstly, the aim was to guarantee a high degree of standardisation. Secondly, both methods allow for constant control over the collected data, constant monitoring of the sample size and respondents' answers. Thirdly, the CATI method ensures the possibility of conducting representative research in the enterprise sector due to the availability of the entire sampling frame (National Business Registry Number database), various sampling procedures and the elimination of the so-called 'clustering' (concentration of entities within geographically close locations). The most important advantage and characteristic of this research method is the fact that based on a properly selected test sample, the results can be generalised to the whole population. Moreover, the CATI method can be combined with online surveys and qualitative methods such as projective tests. Additionally, the CATI and CAWI methods allow for modification of the research tool even after the start of the fieldwork phase.

The sample for the CATI survey was randomly selected. The survey sample included management staff of companies which, according to their declarations, offer energy generation systems from renewable sources. The sampling frame was the Bisnode Poland database, which contains current contact and financial data of companies which operate in Poland. A total of $\mathrm{n}=328$ companies from all over Poland, meeting the selection conditions, were drawn-out of which, $\mathrm{n}=121$ effective interviews were conducted. The randomisation algorithm incorporated into the telephone survey software ensured that each record in the database had an equal chance of being included in the sample. The response rate was 0.74 .

The sample for the CAWI survey also was randomly selected. The sampling frame was the inetpanel.pl database which contains data on active panellists, comprising almost 20,000 adult Poles. In total, $n=500$ effective interviews were conducted. The sample was representative concerning such socio-demographic variables as gender, age, size of the town of residence, and voivodeship. 
In the case of the CATI survey, the prerequisite for the company to be included in the sample was confirmation that it was operating a business related to renewable energy sources. In the case of the CAWI survey, the prerequisite for the respondent to be included in the sample was the feasibility to install renewable energy sources (the respondent should live in a building which enables the installation of such devices).

\section{Results}

DTPs, according to CATI surveys conducted in 2019 among 120 Polish enterprises, should be considered tools that enable the establishment and development of innovative business models. This is evidenced by the data presented in Table 2 .

Table 2. DTPs as tools for establishing and developing innovative business models.

\begin{tabular}{ccc}
\hline Do DTPs Enable the Creation and Development of Innovative Business Models? & Frequency & Percentage \\
\hline Strongly agree & 63 & 52.1 \\
Somewhat agree & 45 & 37.2 \\
Neither agree nor disagree & 12 & 9.9 \\
Somewhat disagree & 1 & 0.8 \\
Total & 121 & 100.0 \\
\hline
\end{tabular}

The vast majority of respondents declared that DTPs allowed for the establishment and development of innovative business models. There were 108 of them, which accounted for $89.3 \%$ of the survey respondents. Thus, DTPs can significantly contribute to the implementation and development of the RES platform, which should be considered one of the innovative, as far as the Polish market is concerned, business models.

The research based on the CATI method also included an exploration of selected structural relationships within the correlations and intergroup comparisons. Table 3 presents respondents' opinions on the impact of DTPs on the establishment and development of innovative business models in the context of company size.

Table 3. DTPs as tools for establishing and developing innovative business models compared to company size.

\begin{tabular}{|c|c|c|c|c|c|c|c|c|}
\hline \multirow{3}{*}{$\begin{array}{l}\text { Do DTPs Enable the Creation and Development of } \\
\text { Innovative Business Models? }\end{array}$} & \multicolumn{8}{|c|}{ Company Size } \\
\hline & \multicolumn{2}{|c|}{ Micro } & \multicolumn{2}{|c|}{ Small } & \multicolumn{2}{|c|}{ Medium } & \multicolumn{2}{|c|}{ Large } \\
\hline & $\mathbf{N}$ & $\%$ & $\mathbf{N}$ & $\%$ & $\mathbf{N}$ & $\%$ & $\mathbf{N}$ & $\%$ \\
\hline Strongly agree & 10 & $83.3 \%$ & 18 & $64.3 \%$ & 15 & $36.6 \%$ & 19 & $48.7 \%$ \\
\hline Somewhat agree & 1 & $8.3 \%$ & 5 & $17.9 \%$ & 24 & $58.5 \%$ & 15 & $38.5 \%$ \\
\hline Neither agree nor disagree & 1 & $8.3 \%$ & 5 & $17.9 \%$ & 1 & $2.4 \%$ & 5 & $12.8 \%$ \\
\hline Somewhat disagree & 0 & $0.0 \%$ & 0 & $0.0 \%$ & 1 & $2.4 \%$ & 0 & $0.0 \%$ \\
\hline Strongly disagree & 0 & $0.0 \%$ & 0 & $0.0 \%$ & 0 & $0.0 \%$ & 0 & $0.0 \%$ \\
\hline
\end{tabular}

The size of the company is not a factor that determines any differences concerning perceptions of the impact the DTPs have on the establishment and development of innovative business models. This was confirmed by a H Kruskal-Wallis intergroup comparison test.

Launching a RES platform based on the DTP can bring measurable benefits. During the CATI survey, this issue was also addressed. Data related to these benefits is presented in Table 4. 
Table 4. The benefits of using DTPs.

\begin{tabular}{|c|c|c|}
\hline Please Specify What Key Benefits Are Generated in Your Business by Using DTPs? & Frequency & Percentage \\
\hline Profit increase & 56 & 46.3 \\
\hline Increase in competitiveness level & 19 & 15.7 \\
\hline Expansion of the product range & 13 & 10.7 \\
\hline Increase in market share & 3 & 2.5 \\
\hline Increase in the innovation level & 6 & 5.0 \\
\hline Increase in the customer count & 2 & 1.7 \\
\hline Improvement of customer service and increase in consumer satisfaction levels & 3 & 2.5 \\
\hline Increase in the number of markets in which the company operates & 2 & 1.7 \\
\hline Increase in the number of business partners & 1 & 0.8 \\
\hline Optimisation of various business processes & 11 & 9.1 \\
\hline Building digital supply chains & 1 & 0.8 \\
\hline Increase in the overall efficiency of the company's operations & 3 & 2.5 \\
\hline $\begin{array}{l}\text { The possibility of being actively involved in the implementation of programmes initiated in } \\
\text { the virtual environment, aimed at expanding the range of products or the customer base }\end{array}$ & 1 & 0.8 \\
\hline Total & 121 & 100.0 \\
\hline
\end{tabular}

By using DTPs, entities that will participate in the design and implementation of the RES platform can achieve a number of benefits. The most important of these refer to an increase in profits (46.3\% of respondents), increase in the level of competitiveness $(15.7 \%)$, expansion of the product range $(10.7 \%)$, and optimisation of various business processes (9.1\%).

Based on the results of the CATI survey, it is worth mentioning the data related to the influence the DTP has on the relations established by the company with its stakeholders. This data is presented in Table 5 .

Table 5. The impact that DTPs have on relations with stakeholders.

\begin{tabular}{|c|c|c|}
\hline $\begin{array}{c}\text { To What Extent Do DTPs Increase the Quality and Intensity of the Relationships Established } \\
\text { by the Company in Which You Perform Your Professional Duties with All } \\
\text { Stakeholders-Including Mainly Suppliers, Contractors, Distributors or Customers? }\end{array}$ & Frequency & Percentage \\
\hline To a very large degree & 44 & 36.4 \\
\hline To a large degree & 47 & 38.8 \\
\hline Neither to a large nor a small degree & 11 & 9.1 \\
\hline To a small degree & 2 & 1.7 \\
\hline To a very small degree & 6 & 5.0 \\
\hline I have no opinion on that subject & 11 & 9.1 \\
\hline Total & 121 & 100.0 \\
\hline
\end{tabular}

The majority of respondents ( 93 of them, i.e., $75.2 \%$ of the total) declared that DTPs increased the quality and intensity of relations with stakeholders, of which 44 respondents $(36.4 \%)$ stated that DTPs had an impact on these relations to a very high degree and 47 respondents $(38.8 \%)$ considered it to be to a high degree. Only eight people $(6.7 \%)$ had the opposite opinion.

Data on the impact of DTPs on the relations with stakeholders can also be considered by taking the size of the company into account. This data can be found in Table 6 . 
Table 6. The company's relationships with the environment compared to the company size.

\begin{tabular}{|c|c|c|c|c|c|c|c|c|}
\hline \multirow{3}{*}{$\begin{array}{l}\text { To What Extent Do DTPs Increase the Quality and } \\
\text { Intensity of the Company's Business Relationships? }\end{array}$} & \multicolumn{8}{|c|}{ Company Size } \\
\hline & \multicolumn{2}{|c|}{ Micro } & \multicolumn{2}{|c|}{ Small } & \multicolumn{2}{|c|}{ Medium } & \multicolumn{2}{|c|}{ Large } \\
\hline & $\mathbf{N}$ & $\%$ & $\mathbf{N}$ & $\%$ & $\mathbf{N}$ & $\%$ & $\mathbf{N}$ & $\%$ \\
\hline To a very large degree & 4 & $33.3 \%$ & 10 & $35.7 \%$ & 15 & $36.6 \%$ & 15 & $38.5 \%$ \\
\hline To a large degree & 5 & $41.7 \%$ & 11 & $39.3 \%$ & 16 & $39.0 \%$ & 14 & $35.9 \%$ \\
\hline Neither to a large nor a small degree & 2 & $16.7 \%$ & 3 & $10.7 \%$ & 5 & $12.2 \%$ & 1 & $2.6 \%$ \\
\hline To a small degree & 0 & $0.0 \%$ & 2 & $7.1 \%$ & 0 & $0.0 \%$ & 0 & $0.0 \%$ \\
\hline To a very small degree & 0 & $0.0 \%$ & 0 & $0.0 \%$ & 5 & $12.2 \%$ & 1 & $2.6 \%$ \\
\hline
\end{tabular}

The company's size is not a factor that influences the possible differences in the aspect related to a very high or high degree of influence of digital technological platforms on the increase in quality and intensity of relations with stakeholders. The data presented above show that a RES platform based on DTPs can become an essential factor for significant intensification of relationships between all players on the RES market, particularly companies that install RES systems and private users (i.e., customers). This was confirmed by a H Kruskal-Wallis intergroup comparison test.

When proceeding to the presentation of the results related to the CATREG (categorical regression), first of all, the components of the optimal scaling model obtained by a descending method shall be presented. These components are shown in Table 7.

Table 7. Components of the optimal scaling model obtained by the descending method.

\begin{tabular}{cccccc}
\hline $\begin{array}{c}\text { Name of Model } \\
\text { Component } \\
\text { (Predictor) }\end{array}$ & Beta Coefficient & $\begin{array}{c}\text { Number of } \\
\text { Degrees of } \\
\text { Freedom (df) }\end{array}$ & F & Significance & $\begin{array}{c}\text { Zero-Order } \\
\text { Correlation }\end{array}$ \\
\hline Question 11. & 0.477 & 12 & 19.774 & 0.001 & 0.361 \\
Question 23. & 0.399 & 11 & 12.976 & 0.001 & 0.233 \\
Question 14. & -0.295 & 3 & 3.881 & 0.012 & -0.162 \\
Question 19. & 0.235 & 2 & 3.527 & 0.167 & 0.150 \\
Question 4. & 0.202 & 1 & 1.941 & 0.193 & 0.130 \\
Question 12. & 0.209 & 2 & 1.675 & 0.170 & 0.116 \\
Question 10. & 0.153 & 1 & 1.919 & 0.036 & 0.135 \\
Question 21. & 0.187 & 2 & 0.443 & 0.325 & -0.066 \\
Question 18. & -0.114 & 1 & 0.981 & Tolerance after & Tolerance before \\
& Partial & Semi-Partial & Transformation & Transformation \\
Question 11. & Correlation & 0.522 & 0.455 & 0.911 & 0.914 \\
Question 23. & 0.449 & -0.279 & 0.386 & 0.877 & 0.965 \\
Question 14. & -0.351 & 0.225 & 0.208 & 0.890 & 0.866 \\
Question 19. & 0.290 & 0.188 & 0.107 & 0.917 & 0.828 \\
Question 4. & 0.245 & 0.204 & 0.079 & 0.865 & 0.847 \\
Question 12. & 0.265 & 0.150 & 0.059 & 0.955 & 0.914 \\
Question 10. & 0.197 & 0.181 & 0.055 & 0.954 & 0.918 \\
Question 21. & 0.236 & -0.110 & 0.042 & 0.936 & 0.928 \\
Question 18. & -0.146 & 0.017 & 0.931 & \\
\hline
\end{tabular}

When analysing the data in Table 7 , it should be noted that the most significant factor influencing attitudes towards DTPs is the economic factor $(0.386$, which explains $38.6 \%$ of the variation in the independent variable) and the socio-demographic factor (0.208). For Question 12, the significance is at the level of 0.055 , which means that attitudes in the surveyed companies are only slightly influenced by the factor related to the establishment and development of innovative business models as a result of using DTPs.

The fit of the optimal scaling model expressed by the multivariate $\mathrm{R}$ was 0.668 , which is considered a moderate (significant) correlation, lying almost on the border of so-called 'substantial correlation', the space of which extends from the value of 0.7 . The total variation 
of the dependent variable, explained by the combined impact of independent variables, was as high as 0.218 . This means that the model explains as much as $21.8 \%$ of the variation in attitudes towards DTPs in companies. This is a substantial value, even though the model consists of a large number of coefficients. A substantial yet acceptable number of factors in the model (nine) reduces the coefficient's original (R-square) value. It is worth noting that the analysis, which attempts to subtract individual coefficients from the model to reduce their number, increases the model's explanatory power. So, the nine variables interact (at least in a mathematical sense) together to form an inseparable whole. The model is statistically significant at a more than satisfactory level, which is $p \leq 0.01$. Visual assessment of the sum of squares for regression and residuals in the ANOVA shows that the regression model explains more than half (53\%) of the variation, which reassures that it is justified. It is worth noting that a similar way of building a model was the basis for the highly evaluated postdoctoral dissertation of Mider [62]. In that study, the fit of the optimal scaling model expressed by the multivariate $\mathrm{R}$ was much lower than in the currently discussed model, namely 0.413 . The model should, therefore, be considered valuable as it explains the correlates of positive evaluations of DTPs.

Figure 1 shows the different components of the optimal scaling model graphically.

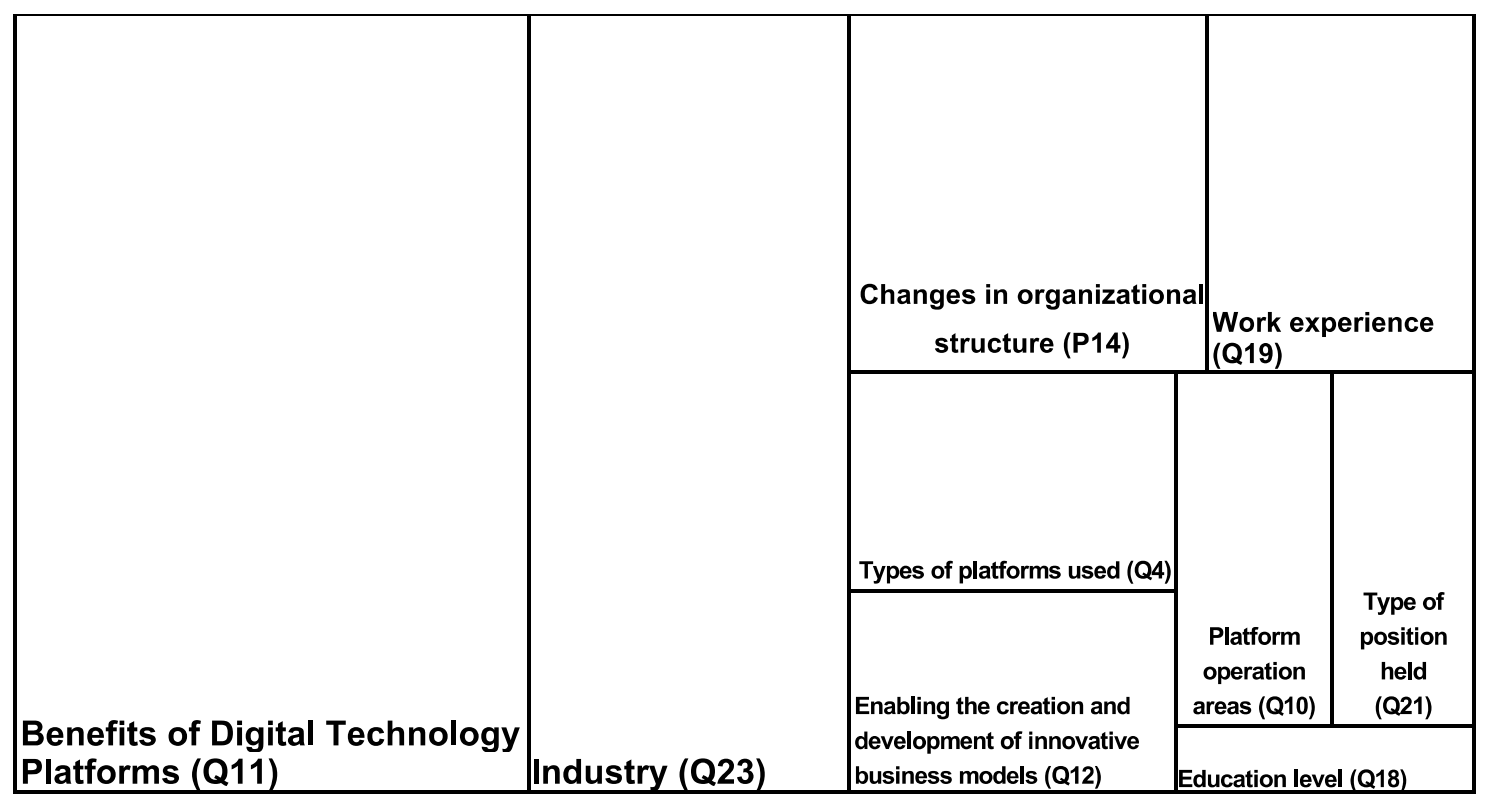

Figure 1. Proportion of importance of the components of the optimal scaling model.

The model includes three groups of factors: economic, structural, and human. Positive attitudes towards DTPs are mainly explained by the number of benefits the digital technology platforms generate in companies (38.6\% of the model fit). The technology factor has long been called an enterprise's strategic weapon, as its importance stems from its deliberate use to add value as a result of changes in manufacturing and control processes $[89,90]$. Positive attitudes towards DTPs are also largely driven by factors of a structural nature, primarily the industry in which the company operates and the intensity of transformations in the company's internal structure (altogether as much as $47.5 \%$, i.e., almost half of the model components). It is worth emphasising that the significance of the structural factor has already been widely recognised for a long time. Douglas North, Nobel Prize winner in economics, claimed that development owes more to organisational progress than to technical progress [91]. On the other hand, the human factor, i.e., the strictly socio-psychological and demographic factors of the respondent, plays a secondary role (in terms of explanatory power) and is represented by characteristics such as job seniority, position, and education (13.8\%). 
When relating the developed model of attitudes towards DTPs to the RES platform discussed in this paper, it should be stated that for the construction and implementation of this platform based on digital technology platforms, it would be necessary to take into account, most of all, the economic factor and scope of possible benefits that individual stakeholders can achieve from the use of such a platform. In this respect, when it comes to stakeholders who will invest a certain amount of money in the development of such a platform, the return on capital allocated to RES platform implementation activities will be of key importance. However, regarding companies installing RES systems, the most important factor is the possibility of getting their offer out to the largest possible group of recipients. Therefore, from their perspective, the RES platform should attract the largest possible number of customers and thus create the ground for rapid acquisition of new customers and the development of their business and gradual profit increase. On the other hand, for customers (i.e., private users wanting to install RES systems), the financial factor will be predominant, i.e., the possibility to employ entities which offer the lowest prices in the market but also the highest quality services.

In order to complement the results of the survey carried out among the beneficiaries of the Operational Programme Innovative Economy, it is worth analysing the data obtained from the CATI survey carried out among the management staff of companies offering systems for generating energy from renewable sources, and the CAWI survey carried out among people who have the technical feasibility to install such systems. With regards to the CATI survey, the respondents were asked, among other things, whether they were interested in using an online platform which would facilitate the selection of a system parameters appropriate for the users' energy demand. This included the power of the equipment, efficiency and loss factors, the calculation of energy yield, benefits and savings from the use of RES systems, and the selection of companies that could install such systems. The analysis of respondents' declarations concerning this issue is presented in Table 8.

Table 8. Declarations of respondents of the CATI survey related to the use of the RES online platform.

\begin{tabular}{ccc}
\hline Would You Be Interested in Using the RES Online Platform? & Frequency & Percentage \\
\hline Yes & 88 & 73.3 \\
No & 32 & 26.7 \\
Total & 121 & 100.0 \\
\hline
\end{tabular}

The majority of respondents ( 88 of them, i.e., $73.3 \%$ of the total) stated that they were inclined to use the functionalities which an online RES platform would offer.

A similar question was asked to respondents of the CAWI survey. The results are presented in Table 9.

Table 9. Declarations of respondents of the CAWI survey related to the use of the RES online platform.

\begin{tabular}{|c|c|c|}
\hline Would You Be Interested in Using the RES Online Platform? & Frequency & Percentage \\
\hline Yes, I am planning or interested in installing the RES platform & 141 & 28.2 \\
\hline $\begin{array}{c}\text { Yes, mainly to find out what the potential of the site is and the possible options, cost and } \\
\text { potential benefits }\end{array}$ & 301 & 60.2 \\
\hline No, I am planning or interested in installing the RES platform, but my knowledge is sufficient & 9 & 1.8 \\
\hline No, at the moment, I do not plan to install it, but I do not exclude such an investment in the future & 25 & 5.0 \\
\hline $\begin{array}{l}\text { Not applicable, not interested in the platform } \\
\text { No, I am not interested at all in the RES }\end{array}$ & 24 & 4.8 \\
\hline Total & 500 & 100.0 \\
\hline
\end{tabular}

People who have the possibility to install RES systems mostly stated that they would be interested in using a platform to choose the right RES solution and the company which would install the system. In total, 442 people, i.e., $88.4 \%$ of those surveyed, expressed this 
opinion - of which 301 people $(60.2 \%)$ stated that they were interested in the RES platform mainly due to the possibility to learn about the potential of the site and the available options and costs associated with the installation of RES systems, and 141 people (28.2\%) stated that they were planning and/or were interested in installing RES. This data clearly indicates that, in the case of using a DTP-based RES online platform, consumers would mainly emphasise the economic factor related to the possible range of benefits resulting from the use of this platform and the installation of RES. This factor, as the most important one, was also included in the model of attitudes towards DTPs.

Representatives of companies that install RES systems were also asked which aspects of such a platform would be crucial for them. The respective data is presented in Table 10.

Table 10. Elements of the RES platform important to respondents.

\begin{tabular}{|c|c|c|c|}
\hline What Would Be Important to You in the Case of a RES Platform? & Frequency & Percentage & Percentage of Valid Ones \\
\hline The possibility to place your advertisement there & 20 & 10.8 & 16.7 \\
\hline $\begin{array}{c}\text { A tool which would prepare simulation related to the potential of } \\
\text { the site and estimations of electricity or heat production, } \mathrm{CO}_{2} \\
\text { emission savings, energy bills savings per year (daily, } \\
\text { quarterly, monthly) }\end{array}$ & 77 & 41.4 & 64.2 \\
\hline Information on possible subsidies for the installation of RES system & 30 & 16.1 & 25.0 \\
\hline $\begin{array}{c}\text { The possibility to place your company in the company database on } \\
\text { the platform. Based on the recommendations, customers could } \\
\text { choose it as a contractor/service provider. This way you would } \\
\text { gain new customers }\end{array}$ & 27 & 14.5 & 22.5 \\
\hline Not applicable, not interested in the platform & 32 & 17.2 & 26.7 \\
\hline Total & 186 & 100.0 & $155.0 *$ \\
\hline
\end{tabular}

* A value higher than $100 \%$ because each respondent could give more than one answer.

Respondents, referring to those elements of the RES platform that would be important for them, mainly indicated the possibility of making simulations related to the potential of a given site, including energy bill savings. The key factor here is the one already mentioned and that results from the constructed model of attitudes towards DTPs- the economic factor is strongly linked to the benefits that can be generated as a result of using these platforms, which includes the establishment and development of innovative business models.

The participants of the CATI survey were also asked about the expenses they might agree to incur to obtain access to the RES platform. These expenses are presented in Table 11.

Table 11. The amount of expenditure that could be incurred by companies for access to the RES platform.

\begin{tabular}{ccc}
\hline How Much Would You Be Willing to Spend per Year to Access the RES Platform? & Frequency & Percentage \\
\hline Nothing, we are not interested in the platform & 33 & 27.3 \\
up to 800 PLN & 4.3 & 17 \\
801-1500 PLN & 14.0 & 35 \\
1501-3000 PLN & 28.9 & 16.6 \\
mone than 4501 PLN & 12 & 9.9 \\
Total & 121 & 100.0 \\
\hline
\end{tabular}

Respondents are usually willing to spend [on the online RES platform] between 1501 and 3000 PLN per year (35 persons, i.e., $29.2 \%$ of the total). A significant number of respondents indicated amounts between 3001 and 4500 PLN (20 people, i.e., 16.7\%), and between 801 and 1500 PLN (17 people, i.e., 14.2\% of the total). Respondents are, therefore, willing to incur certain expenses in exchange for using the RES platform based on DTPs and the possibility to benefit from a variety of related advantages. 
In the conclusion, the research, which used CATI and CAWI methods and regression analysis CATREG, found that the attitude of both representatives of enterprises dealing with the installation of renewable energy installations and people who use such installations, in relation to the RES platform, is mostly positive, and what would induce them to use such a platform, even at the price of bearing certain costs, is the economic factor resulting from specific benefits.

Research has shown that DTPs can be the basis for establishing and developing innovative business models such as the online RES platform, which includes many modern functionalities which have not been available on the market yet. The interest in this platform is relatively high, which is certainly due to the widespread promotional campaigns emphasising both innovativeness and tools and systems allowing to reduce negative human impact on the natural environment. The online RES platform based on DTPs can be an important factor for building a competitive advantage in the RES market. Therefore, its implementation is reasonable and necessary from the point of view of all entities operating in this market.

\section{Discussion and Conclusions}

In conclusion, it is worth mentioning that the above-mentioned RES platform, which will enable intermediation between contractors installing RES systems and persons willing to purchase such systems, should be considered both a DTP-based solution and an innovative and digital business model. A platform like this will have features of a DTP, such as multiple functionalities (it will be possible not only to contact a specific company or investor, but also to calculate the annual energy consumption and demand and to determine the most important parameters of a RES installation) and high interoperability [12] It is worth noting that currently, there are a number of platforms which are already used on the energy market in relation to RES and successfully operate on the basis of a DTP. In addition to managing energy systems, such platforms allow selling unconsumed energy, monitoring energy demand, and quickly responding to any demand changes, undertaking extensive cooperation by individual participants of the energy market, monitoring power grids, or combining individual infrastructure components into large networks [92,93].

The RES platform should also be considered as an innovative and digital business model. In fact, in the literature, a number of DTPs operating in the energy market and RES market have been recognised as such a model [94]. It is characterised by a strong reliance on modern digital technologies, implying a new way of doing business, in which the intensification of interactions between different actors (stakeholders) and the continuous value generation are the dominant features [95-97]. It is worth emphasising that strong customer orientation, which is characteristic of modern business models, will be crucial in the planned RES platform. In this regard, it is important to personalise the offer for customers (a platform based on a DTP provides the ground for customised configuring and selecting products and services, rather than just using ready-made packages-a curated computing model), as well as for the algorithmisation and automation of the sales of products and services (a number of choices rated to products and services are made automatically by the platforms, based on a variety of algorithms, which make it easier for customers to purchase goods) [98].

In this context, it is necessary to mention the category of prosumers, i.e., consumers who become co-creators of innovation and co-creators of the added value of the enterprise; therefore, they take an active part in its functioning and the practical implementation of innovative business models $[99,100]$. Prosumers are particularly present in the RES market because they become producers of energy from renewable sources by installing a system in their home. In this way, their knowledge in this field and their experience, acquired while using RES, can become a source of innovation for companies using the RES platform [101]. This is because such a platform, thanks to the possibility of quick contact, can be a fundamental factor in establishing long-term relationships between companies and customers. With regard to the above, it is worth referring to Nordström and Biaström's concept, which 
points out that consumers are the primary drivers of innovation creation [102]. The RES platform can, therefore, play the role of an "open innovation" in which a UIC (user innovation community) is created [103]. Due to the positive attitudes towards its construction, such a platform-including either companies installing RES systems and consumers, and the possibility of generating multiple benefits-can be a market success.

It is necessary to emphasize that RES have many advantages. However, one should not forget about certain threats and barriers that appear in connection with the implementation of projects in this field. This concerns particular issues related to cybersecurity and the possibility of violating data protection, theft of various information, or damage to IT systems. Such risks apply to virtually every digital technology platform. They should be effectively counteracted, including, inter alia, by formulating the principles of reducing risks in the field of cyber-threats. An important caveat also applies to the fact that RES installations are associated with specific costs that can only be recovered after many years of use. This may result in certain barriers in access to renewable energy, especially on the part of private users. Such barriers are compounded by the fact that renewable energy is not available everywhere, and its effective use largely depends on weather conditions.

It is worth mentioning that there is a need for further empirical research in relation to the RES platform discussed in this paper. This could examine what additional functionalities it could include, taking into account the needs of RES market participants and how it could integrate not only the actions taken by service companies and consumers, but also by energy suppliers and public organizations, including local government units. This is an area for further research.

The presented scientific work has led to the taking up of issues that have not been signalled strongly enough in the scientific literature so far. First of all, for the first time, it was established that digital technology platforms can significantly contribute to the promotion of renewable energy technologies through the possibility of creating completely new, innovative business models. The planned RES platform can be considered as such a model, being strongly based on modern technologies, and integrating many entities that operate in the energy sector. In addition, the study found that the economic factor is of decisive importance for the popularization of solutions in the field of RES based on DTPs. The arrangements in this regard make a significant contribution to the knowledge of management and IT.

\section{Research Limitations}

One of the research limitations is the test sample in the "Business models based on DTPs" project. This sample includes enterprises that applied for and received co-funding under the Innovative Economy Operational Programme for investments related to the implementation and development of DTPs. Therefore, representatives of these enterprises may have positive attitudes towards such platforms, which may have significantly influenced their declarations regarding the implementation and use of DTPs. Therefore, to confirm the results obtained, further research would have to be carried out, including those companies that did not obtain or did not apply for the above-mentioned funds. It should also be said that the obtained results concern the attitudes of the managers of Polish companies and, due to cultural and social differences and business conditions, they could not be blindly analysed in the context of the situation in other countries.

It is necessary to also distinguish those limitations related to the CATREG optimal scaling. One of such limitation is related to the permissible number of predictors-independent variables, which amounts to 200 (in the case of CATI survey results, this condition is irrelevant, as the number of predictors rarely exceeds 100). At the same time, each variable should have a minimum of ten and, preferably, twenty units of analysis. Optimal scaling is therefore not advisable in the case of small sample sizes. Failure to take this condition into account results in unstable regression lines. Another limitation is the inherent defect of all regression methods, which provide information on the existence or absence of relations between variables but do not provide any knowledge about the cause-and-effect relation- 
ship of such relations. An important reservation also concerns the fact that depending on the type and number of variables included in the model, different result values are obtained, and it is difficult to decide which of the constructed models is best. The choice is made by the researcher, taking into account the structure of the obtained results.

Funding: This research was funded by Warsaw School of Economics, grant number: KNOP/BMN18/04/18. The APC was funded by Warsaw University of Technology.

Institutional Review Board Statement: Not applicable.

Informed Consent Statement: Not applicable.

Data Availability Statement: The data presented in this study are available on request from the corresponding author.

Conflicts of Interest: The author declare no conflict of interest.

\section{References}

1. Wachal, R. Humanities and Computers. A Personal View. N. Am. Rev. 1971, 256, 30-33.

2. Schumacher, A.; Sihn, W.; Erol, S. Automation, digitization and digitalization and the implications for manufacturing processes. In: Innovation and Sustainability 2016. In Proceedings of the International Scientific Conference, Bucharest, Romania, 28-29 October 2016; University Politehnica of Bucharest: Bucharest, Romania, 2016.

3. Ciriello, R.F.; Richter, A.; Schwabe, G. Digital Innovation. Bus. Inf. Syst. Eng. 2018, 60, 563-569. [CrossRef]

4. Eaton, B.D. The Dynamics of Digital Platform Innovation: Unfolding the Paradox of Control and Generativity in Apple's iOS; The London School of Economics and Political Science: London, UK, 2012.

5. Yoo, Y.; Lyytinen, K.; Boland, R.; Berente, N.; Gaskin, J.; Schultz, D.; Srinivasan, N. The Next Wave of Digital Innovation: Opportunities and Challenges; Institute of Business \& Information Technology Fox School of Business \& Administration Temple University: Philadelphia, PA, USA, 2010.

6. Evans, P.C.; Gawer, A. The Rise of the Platform Enterprise. A Global Survey; The Center for Global Enterprise: New York, NY, USA, 2016.

7. Cusumano, M.A. Platforms Versus Products: Observations from the Literature and History. In Advances in Strategic Management; Kahl, S., Silverman, B., Cusumano, M.A., Eds.; Emerald Group Publishing: Bingley, UK, 2012; pp. 35-67.

8. Reuver, M.; Sørensen, C.; Basole, R.C. The digital platforms: A research agenda. J. Inf. Technol. 2015, 4, 124-135. [CrossRef]

9. Bonina, C.; Koskinen, K.; Eaton, B.; Gawer, A. Digital platforms for development: Foundations and research agenda. Inf. Syst. J. 2021, 31, 869-902. [CrossRef]

10. Constantinides, P.; Henfridsson, O.; Parker, G. Platforms and Infrastructures in the Digital Age. Inf. Syst. Res. 2018, 2, 1-20. [CrossRef]

11. Le Hong, H.; Howard, C.; Gaughan, D.; Logan, D. Building a Digital Business Technology Platform; Gartner: Stamford, CT, USA, 2016.

12. Sun, R.; Keating, B.; Gregor, S. Information Technology Platforms: Definition and Research Directions. In Proceedings of the 26th Australasian Conference on Information Systems (ACIS), Auckland, New Zealand, 30 November-4 December 2015; Australasian Association for Information Systems: Adelaide, Australia, 2015; pp. 1-17.

13. Corin-Stig, D. Technology Platforms. Organizing and Assessing Technological Knowledge to Support Its Reuse in New Applications; Department of Product and Production Development Chalmers University of Technology: Gothenburg, Sweden, 2015.

14. European Commission. Technology Platforms from Definition to Implementation of a Common Research Agenda; European Commission: Luxembourg, 2004.

15. Fichman, R.G. Real options and IT platform adoption: Implications for theory and practice. Inf. Syst. Res. 2004, 15, 132-154. [CrossRef]

16. Zott, C.; Amit, R.; Massa, L. The business model: Recent developments and future research. J. Manag. 2011, 37, 1019-1042.

17. Cigaina, M.; Riss, U.V. Digital Business Modeling. A Structural Approach toward Digital Transformation. Version 2. Available online: https:/ /news.sap.com/2016/05/digital-business-modeling-a-structural-approach-toward-digital-transformation/ (accessed on 22 June 2021).

18. Brousseau, E.; Penard, T. The economics of digital business models: A framework for analyzing the economics of platforms. Rev. Netw. Econ. 2007, 6, 82-93. [CrossRef]

19. Morgan, L.; Hintermann, F.; Vazirani, M. Five Ways to Win with Digital Platforms; Accenture: Dublin, Ireland, 2016.

20. Täuscher, K.; Laudien, S.M. Understanding Platform Business Models: A Mixed Methods Study of Marketplaces. Eur. Manag. J. 2018, 36, 319-329. [CrossRef]

21. Kotarba, M. Digital Transformation of Business Models. Found. Manag. 2018, 10, 123-142. [CrossRef]

22. Tidd, J. A Review of Innovation Models; Imperial College London: London, UK, 2006.

23. Jetter, M.; Satzger, G.; Neus, A. Technological Innovation and Its Impact on Business Model, Organization and Corporate Culture-IBM's Transformation into a Globally Integrated, Service Oriented Enterprise. Bus. Inf. Syst. Eng. 2009, 1, 37-45. [CrossRef] 
24. Teece, D.J.; Linden, G. Business models, value capture, and the digital enterprise. J. Organ. Des. 2017, 8, 8-10. [CrossRef]

25. Faber, A.; Matthes, F.; Michel, F. Digital Mobility Platforms and Ecosystems. State of the Art Report; Technical University of Munich: Munich, Germany, 2016.

26. Duch-Brown, N.; Rossetti, F. Digital platforms across the European regional energy markets. Energy Policy 2020, 144, 1-11. [CrossRef]

27. Zhou, J. The Digital Energy Platform (Revolution). Available online: https://e-file.huawei.com/-/media/EBG/Download_ Files/Publications/en/ict_energy_internet_extra/The_Digital_Energy_Platform_R_evolution.pdf (accessed on 20 May 2021).

28. Morris, M.; Hardy, J.; Gaura, E.; Hannon, M.; Morstyn, T. Policy E Regulatory Landscape Review Series-Working Paper 2. Digital Energy Platforms; Energy Revolution Research Centre. University of Strathclyde: Strathclyde, UK, 2020.

29. GE Power; GE Renewable Energy. The Digital Energy Transformation; GE Power: Boston, MA, USA, 2018.

30. Kloppenburg, S.; Boekelo, M. Digital platforms and the future of energy provisioning: Promises and perils for the next phase of the energy transition. Energy Res. Soc. Sci. 2019, 49, 68-73. [CrossRef]

31. Motlagh, N.H.; Mohammadrezaei, M.; Hunt, J.; Zakeri, B. Internet of Things (IoT) and the Energy Sector. Energies 2020, $13,494$. [CrossRef]

32. Giraldo, S.; Rotta La, D.; Nieto-Londono, C.; Vasquez, R.E.; Escudero-Atehortua, A. Digital Transformation of Energy Companies: A Colombian Case Study. Energies 2021, 14, 2523. [CrossRef]

33. Pauli, T.; Fielt, E.; Matzner, M. Digital Industrial Platforms. Bus. Inf. Syst. Eng. 2021, 63, 181-190. [CrossRef]

34. Gerrikagoitia, J.K.; Unamuno, G.; Urkia, E.; Serna, A. Digital Manufacturing Platforms in the Industry 4.0 from Private and Public Perspectives. Appl. Sci. 2019, 14, 2934. [CrossRef]

35. Fraile, F.; Sanchis, R. Reference Models for Digital Manufacturing Platforms. Appl. Sci. 2019, 20, 4433. [CrossRef]

36. Kaminski, V. A Practical Approach to Risk Management; Allegro Development Corporation: Dallas, TX, USA, 2011.

37. Dacko, M.; Płonka, A.; Satoła, Ł.; Dacko, A. Sustainable Development According to the Opinions of Polish Experts. Energies 2021 14, 5325. [CrossRef]

38. Serowaniec, M. Sustainable Development Policy and Renewable Energy in Poland. Energies 2021, 14, 2244. [CrossRef]

39. Zarra, A.; Simonelli, F.; Lenaerts, K.; Luo, M.; Baiocco, S.; Ben, S.; Li, W.; Echikson, W.; Kilhoffer, W. Sustainability in the Age of Platforms; Centre for European Policy Studies-Academy of Internet Finance: Brussels, Belgium, 2019.

40. Tiwana, A. Platform Ecosystems: Aligning Architecture, Governance, and Strategy; Morgan Kaufmann: Amsterdam, The Netherlands, 2014.

41. Ramamurthy, A.; Jain, P. The Internet of Things in the Power Sector: Opportunities in Asia and the Pacific; Asian Development Bank: Mandaluyong, Philippines, 2017.

42. Bell, K.; Gill, S. Delivering a highly distributed electricity system: Technical, regulatory and policy challenges. Energy Policy 2018, 113, 765-777. [CrossRef]

43. IRENA. Innovation Landscape for a Renewable-Powered Future: Solutions to Integrate Variable Renewables; International Renewable Energy Agency: Abu Dhabi, United Arab Emirates, 2019.

44. Ofgem. Ofgem's Future Insights Series: Flexibility Platforms in Electricity Markets; Crown Copyright: London, UK, 2019.

45. Bañales, S. The enabling impact of digital technologies on distributed energy resources integration. J. Renew. Sustain. Energy 2020, 12, 45301. [CrossRef]

46. Singh, M.; Jiao, J.; Klobasa, M.; Frietsch, R. Making Energy-transition headway: A Data driven assessment of German energy startups. Sustain. Energy Technol. Assess. 2021, 47, 101322. [CrossRef]

47. Botsaris, P.N.; Giourka, P.; Papatsounis, A.; Dimitriadou, P.; Goitia-Zabaleta, N.; Patsonakis, C. Developing a Business Case for a Renewable Energy Community in a Public Housing Settlement in Greece-The Case of a Student Housing and Its Challenges, Prospects and Barriers. Sustainability 2021, 13, 3792. [CrossRef]

48. Shubin, N.G.; Krasilnikov, K.A.; Krasilnikov, M.I.; Nepsha, F.S. Simulation of an Applied Microgrid Control System Based on a Digital Platform. In Proceedings of the of the 2020 Ural Smart Energy Conference (USEC), Ekaterinburg, Russia, 13-15 November 2020; Institute of Electrical and Electronics Engineers: Piscataway, NJ, USA; pp. 126-129.

49. Light, A.; Briggs, J. Crowdfunding Platforms and the Design of Paying Publics. In Proceedings of the $2017 \mathrm{CHI}$ Conference on Human Factors in Computing Systems, Denver, CO, USA, 6-11 May 2017; Association for Computing Machinery: New York, NY, USA, 2017; pp. 797-809. [CrossRef]

50. Wang, S.; Taha, A.F.; Wang, J.; Kvaternik, K.; Hahn, A. Energy Crowdsourcing and Peer-to-Peer Energy Trading in BlockchainEnabled Smart Grids. IEEE Trans. Syst. Man Cybern. Syst. 2019, 99, 1-12. [CrossRef]

51. Menzel, T.; Teubner, T. Green energy platform economics-understanding platformization and sustainabilization in the energy sector. Int. J. Energy Sect. Manag. 2020, 15, 456-475. [CrossRef]

52. Abdollahi, G.; Leimstoll, U. A Classification for Business Model Types in E-commerce. In Proceedings of the Seventeenth Americas Conference on Information Systems, Detroit, MI, USA, 4-7 August 2011; Association for Information Systems: Detroit, MI, USA, 2011; pp. 1-14.

53. Hednam, J.; Kalling, T. Analysing e-business Models. In Proceedings of the towards the Knowledge Society, eCommerce, eBusiness and eGovernment The Second IFIP Conference on E-Commerce, E-Business, E-Government (I3E 2002), Lisbon, Portugal, 7-9 October 2002; International Federation for Information Processing: Lisbon, Portugal, 2001; pp. 259-270. 
54. Rio, R. Digital Technologies for Thermal Power Plants Improves Performance and ROI. Available online: https://www.arcweb. com/blog/digital-technologies-thermal-power-plants-improves-performance-roi (accessed on 10 June 2021).

55. Liu, W.; Wen, F.; Xue, Y. Power-to-gas technology in energy systems: Current status and prospects of potential operation strategies. J. Modern Power Syst. Clean Energy 2017, 5, 439-450. [CrossRef]

56. Xu, B.; Wang, J.; Wang, X.; Liang, Z. A case study of digital-twin-modelling analysis on power-plant-performance optimizations. Clean Energy 2019, 3, 227-234. [CrossRef]

57. Hewitt, S.; Margetts, L.; Revell, A. Building a Digital Wind Farm. Arch. Comput. Methods Eng. 2017, 25, 879-899. [CrossRef]

58. GE Renewable Energy. Digital Wind Farm. The Next Evolution of Wind Energy; GE Renewable Energy: Boston, MA, USA, 2016.

59. IRENA. Future of Wind. Deployment, Technology, Grid Integration and Socio-Economic Aspects (A Global Energy Transformation Paper); International Renewable Energy Agency: Abu Dhabi, United Arab Emirates, 2019.

60. Robak, S.; Raczkowski, R.M. Substations for offshore wind farms: A review from the perspective of the needs of the Polish wind energy sector. Bull. Pol. Acad. Sci. 2018, 66, 517-528. [CrossRef]

61. Alarcon, A.D. (Ed.) The Digital Revolution of Hydropower in Latin American Countries; Inter-American Development Bank: Washington, DC, USA, 2019.

62. Kougias, I.; Aggidis, G.; Avellan, F.; Deniz, S.; Lundin, U.; Moro, A.; Muntean, S.; Novara, D.; Pérez-Díaz, J.I.; Quaranta, E.; et al. Analysis of emerging technologies in the hydropower sector. Renew. Sustain. Energy Rev. 2019, 113, 109257. [CrossRef]

63. Yang, W. Hydropower Plants and Power Systems. Dynamic Processes and Control for Stable and Efficient Operation; Uppsala University: Uppsala, Sweden, 2017.

64. Agostini, M.; Corbetti, C.; Ogbonna, D.; Stark, M. Hydro'a Digital Generation. Transforming for the Future of Hydropower; Accenture: Dublin, Ireland, 2020.

65. Quaranta, E.; Bonjean, M.; Cuvato, D.; Nicolet, C.; Dreyer, M.; Gaspoz, A.; Rey-Mermet, S.; Boulicaut, B.; Pratalata, L.; Pinelli, M.; et al. Hydropower Case Study Collection: Innovative Low Head and Ecologically Improved Turbines, Hydropower in Existing Infrastructures, Hydropeaking Reduction, Digitalization and Governing Systems. Sustainability 2020, 12, 8873. [CrossRef]

66. Abe, R.; Taoka, H.; McQuilkin, D. Digital Grid: Communicative Electrical Grids of the Future. IEEE Trans. Smart Grid 2011, 2, 399-410. [CrossRef]

67. Kumar, N.M.; Chand, A.A.; Malvoni, M.; Prasad, K.A.; Mamun, K.A.; Islam, F.R.; Chora, S.S. Distributed Energy Resources and the Application of AI, IoT, and Blockchain in Smart Grids. Energies 2020, 13, 5739. [CrossRef]

68. Lopez-Garcia, D.; Arango-Manrique, A.; Carvajal-Quintero, S.X. Integration of distributed energy resources in isolated microgrids: The Colombian paradigm. TecnoLógicas 2018, 21, 13-29. [CrossRef]

69. Sanwal, D.; Gusain, D.; Leena, G.; Verma, M. Distributed energy resources: Issues and challenges. Int. J. Adv. Res. 2018, 6, 1127-1132. [CrossRef]

70. Galperova, E.; Mazurova, O. Digitalization and Energy Consumption. Adv. Intell. Syst. Res. 2019, 169, 55-61. [CrossRef]

71. Verma, P.; Savickas, R.; Buettner, S.M.; Strüker, D.; Kjeldsen, O.; Wamg, X. Digitalization: Enabling the new phase of energy efficiency. In Proceedings of the Regulatory and Policy Dialogue Addressing Barriers to Improve ENERGY Efficiency, Geneva, Switzerland, 22-25 September 2020; Group of Experts on Energy Efficiency: Geneva, Switzerland, 2020.

72. Tleppayev, A. Digitalisation and energy: World experience and evidence of correlation from Kazakhstan. Econ. Ann. -XXI 2019, 176, 56-64. [CrossRef]

73. Standar, A.; Kozera, A.; Satoła, Ł. The Importance of Local Investments Co-Financed by the European Union in the Field of Renewable Energy Sources in Rural Areas of Poland. Energies 2021, 14, 450. [CrossRef]

74. Rakowska, J.; Ozimek, I. Renewable Energy Attitudes and Behaviour of Local Governments in Poland. Energies 2021, 14, 2765. [CrossRef]

75. Tolstolesova, L.; Glukhikh, I.; Tumanova, N.; Arzikulov, O. Digital Transformation of Public-Private Partnership Tools. Energies 2021, 14, 121. [CrossRef]

76. Alloisio, I. Public-Private Partnerships: A focus on Energy Infrastructures and Green Investments. ICCG Reflect. 2014, $22,1-11$.

77. Jia, M.; Komeily, A.; Wang, Y.; Srinivasan, R.S. Adopting Internet of Things for the development of smart buildings: A review of enabling technologies and applications. Autom. Constr. 2019, 101, 111-126. [CrossRef]

78. Strielkowski, W.; Streimikiene, D.; Fomina, A.; Semenova, E. Internet of Energy (IoE) and High-Renewables Electricity System Market Design. Energies 2019, 12, 4790. [CrossRef]

79. Gerring, J. Social Science Methodology: A Criterial Framework; Cambridge University Press: New York, NY, USA, 2001.

80. Soper, J.C.; Walstad, W.B. On Measuring Economic Attitudes. J. Econ. Educ. 1983, 14, 4-17. [CrossRef]

81. Garcia-Santillan, A.; Moreno-Garcia, E.; Carlos-Castro, J.; Zamudio-Abdala, J.H.; Garduno-Trejo, J. Cognitive, Affective and Behavioral Components That Explain Attitude toward Statistics. J. Math. Res. 2012, 5, 8-16. [CrossRef]

82. Millar, M.G.; Tesser, A. Effects of Affective and Cognitive Focus on the Attitude-Behavior Relation. J. Personal. Soc. Psychol. 1986, 51, 270-276. [CrossRef]

83. Bizer, G.Y.; Krosnick, J.A.; Holbrook, A.L.; Wheeler, S.C.; Rucker, D.D.; Petty, R.E. The Impact of Personality on Cognitive, Behavioral, and Affective Political Processes: The Effects of Need to Evaluate. J. Personal. 2004, 72, 996-1027. [CrossRef]

84. Kooij, A.J. Prediction Accuracy and Stability of Regression with Optimal Scaling Transformations. Available online: https: / / openaccess.leidenuniv.nl/handle/1887/12096 (accessed on 17 June 2021).

85. Greenacre, M.J. Theory and Applications of Correspondence Analysis; Academic Press: London, UK, 1984. 
86. Kruskal, B. Multidimensional scaling by optimizing goodness of fit to a nonmetric hypothesis. Psychometrika 1984, $29,1-28$. [CrossRef]

87. Guttman, L. A general nonmetric technique for finding the smallest coordinate space for a configuration of points. Psychometrika 1968, 33, 469-506. [CrossRef]

88. Mider, D. Polacy Wobec Przemocy Politycznej. Politologiczno-Socjologiczne Studium Ocen Moralnych; Dom Wydawniczy "Elipsa": Warszawa, Poland, 2017.

89. Porter, M.; Millar, V.E. How Information Technology gives You Competitive Advantage. Harv. Bus. Rev. 1985, 64, 149-160.

90. Wiseman, C. Strategy and Computers: Information Systems as Competitive Weapons; Dow Jones-Irwin: Homewood, PA, USA, 1985.

91. Acemoglu, D. Introduction to Modern Economic Growth; Princeton University Press: Princeton, NJ, USA, 2009.

92. OECD. A Chain Reaction: Disruptive Innovation in the Electricity Sector. Available online: https://www.oecd.org/competition/ A-chain-reaction-disruptive-innovation-in-the-electricity-sector.pdf (accessed on 24 June 2021).

93. Küfeoğlu, S.; Liu, G.; Anaya, K.; Pollitt, G. Digitalisation and New Business Models in Energy Sector. Available online: https:/ / www.repository.cam.ac.uk/handle/1810/294125 (accessed on 24 June 2021).

94. Giehl, J.; Göcke, H.; Grosse, B.; Kochems, J.; Müller-Kirchenbauer, J. Survey and Classification of Business Models for the Energy Transformation. Energies 2020, 13, 2981. [CrossRef]

95. Veit, D.; Clemons, E.; Benlian, A.; Buxmann, P.; Hess, T.; Spann, M.; Kundisch, D.; Leimeister, J.M.; Loos, P. Business Models: An Information Systems Research Agenda. Bus. Inf. Syst. Eng. 2014, 6, 45-53. [CrossRef]

96. Planing, P. Will digital boost circular? Evaluating the impact of the digital transformation on the shift towards a circular economy. Int. J. Manag. Cases 2017, 19, 22-31.

97. Tärnell, C. Implementing Digital Business Strategies. A Study of the Impact and Application in the Medical Technology Industry; KTH Royal Institute of Technology School of Industrial Engineering and Management: Stockholm, Sweden, 2018.

98. Filiciak, M. Treści Cyfrowe. Przemiany Modeli Biznesowych i Relacji Między Producentami i Konsumentami; MGG Conferences: Warszawa, Poland, 2012.

99. Ritzer, G.; Jurgenson, M. Production, Consumption, Prosumption. J. Consum. Cult. 2010, 10, 13-36. [CrossRef]

100. Prahalad, C.K.; Ramaswamy, V. Co-creation experiences: The next practice in value creation. J. Interact. Mark. 2004, 18, 5-14. [CrossRef]

101. Appelbaum, S.H.; Profka, E.; Depta, A.M.; Petrynski, B. Impact of business model change on organizational success. Ind. Commer. Train. 2018, 50, 41-54. [CrossRef]

102. Nordström, K.; Biaström, M. Emergence of dominant design in probiotic functional food development. Br. Food J. 2020, 104, 713-723. [CrossRef]

103. Ma, J.; Lu, Y.; Gupta, S. User innovation evaluation: Empirical evidence from an online game. Decis. Support Syst. 2019, 117, 113-123. [CrossRef] 